\title{
PENDIDIKAN KARAKTER DALAM PEMBELAJARAN SEJARAH UNTUK MENINGKATKAN SIKAP NASIONALISME SISWA SMA KOTA PADANG
}

\author{
Sermal, Refli Surya Barkara \\ Prodi Tadris IPS-Sejarah Fakultas Tarbiyah dan Keguruan UIN IB Padang
}

\begin{abstract}
Abstrak
Pendidikan Indonesia saat ini masih menghadapi berbagai masalah. Capaian hasil pendidikan masih belum memenuhi hasil yang diharapkan. Proses pendidikan masih menitikberatkan dan memfokuskan capaiannya secara kognitif. Sementara, aspek afektif pada diri peserta didik yang merupakan bekal kuat untuk hidup di masyarakat belum dikembangkan secara optimal. maraknya fenomena perilaku-perilaku yang disebabkan rendahnya sikap nasionalisme siswa seperti siswa kurang menggunakan bahasa indonesia yang baik dan benar, banyak ditemukan siswa tidak mau mengikuti pelaksanaan upacara bendera dengan baik dan benar. Pada akhirnya menimbulkan pertanyaan apakah pembelajaran sejarah telah dilaksanakan dengan baik, lalu kenapa sikap nasionalisme siswa masih rendah
\end{abstract}

Kata Kunci : Pendidikan karakter, Pembelajaran Sejarah, Nasionalisme

\section{Pendahuluan}

Pendidikan memegang peranan yang sangat penting dalam peningkatan kualitas sumber daya manusia di sebuah negara. Pendidikan adalah suatu hal yang mutlak yang harus dipenuhi untuk meningkatkan taraf hidup bangsa agar menjadi sejahtera, diharapkan pendidikan mampu menggali dan mengembangkan potensi peserta didik sehingga memberikan pemahaman keagamaan yang tinggi, pengendalian diri, kepribadian, kecerdasan serta memiliki akhlak yang mulia sebagai bekal hidup ditengah-tengah masyarakat.

Derasnya arus globalisasi, membawa pengaruh bagi kehidupan suatu negara, ternyata berpengaruh juga dengan nilai-nilai nasionalisme Indonesia dan mempengaruhi mutu pendidikan. Generasi muda sebagai generasi penerus bangsa harusnya memiliki tanggung jawab dalam usaha membina dan melestarikan nasionalisme, sebab.

Nasionalisme telah menjadi jembatan emas bagi para pahlawan untuk memproklamirkan kemerdekaan ini. Tanpa adanya pembinaan Nasionalisme terhadap generasi muda kita khawatir, bangsa ini terjerumus dalam kolonialisme baru sesuai dengan jamannya. Berbagai pengaruh luar yang masuk dengan adanya globalisasi tentu akan mendatangkan sebuah tantangan baru dalam 
tatanan kehidupan berbangsa dan bernegara. Berkaitan dengan fenomena pengaruh dari globalisasi yang sangat mengkhawatirkan masyarakat terlebih pada generasi muda, pemerintah mengeluarkan kebijakan mengenai pendidikan, dengan menanamkan nilai-nilai karakter khususnya dalam mata pelajaran sejarah memberikan arti yang strategis dalam pembentukan watak dan peradaban bangsa yang bermatabat serta memiliki rasa kebangsaan dan cinta tanah air. Salah satu upaya dalam pembentukan watak dan peradaban bangsa yaitu dengan pembelajaran sejarah.

Mata pelajaran sejarah merupakan mata pelajaran yang wajib diberikan pada jenjang pendidikan menengah (SMA atau MA dan SMK atau MAK). Sebagaimana dipertegas oleh Permendiknas No. 22 Tahun 2006 tentang standar isi bahwa mata pelajaran sejarah Indonesia memiliki arti yang strategis dalam pembentukan watak dan peradaban bangsa yang bermartabat serta dalam pembentukan rasa kebangsaan dan cinta tanah air. Pendidikan karakter dapat diintegrasikan dalam mata pelajaran sejarah materi pembelajaran yang berkaitan dengan nilai dan norma dieksplisitkan dan dikaitkan dengan konteks kehidupan sehari-hari. Dengan demikian pembelajaran nilai-nilai karakter tidak hanya pada tataran kognitif, tetapi menyentuh pada internalisasi dan pengamalan nyata dalam kehidupan sehari-hari (Nurul Fajri, 2013:4).

Dalam pengajaran sejarah, masih banyak yang perlu dibenahi seperti porsi pengajaran yang berasal dari ranah kognitif dan afektif, kedua ranah tersebut harus selalu ada dalam pengajaran sejarah (Dyah kumalasari, 2003:4).

Pengajaran sejarah yang mengutamakan fakta keras perlu mendapat perhatian yang signifikan karena pengajaran sejarah yang demikian hanya akan menimbulkan rasa bosan di kalangan peserta didik dan pada giliran nya akan menimbulkan keengganan untuk mempelajari sejarah (Soedjadmoko, 1976:13).

Kemudian dipertegas oleh Dyah kumalasari (2003:4) bahwa sejarah tidak akan berfungsi dalam proses pendidikan yang menjurus kearah pertumbuhan dan pengembangan karakter bangsa apabila nilai-nilai sejarah tersebut belum terwujud dalam pola perilaku yang nyata. Untuk mewujudkan pola perilaku maka pengajaran sejarah berperan penting dalam pembentukan karakter perilaku sehingga menyadarkan peserta didik untuk mengenal diri dan lingkungannya, serta memberikan perspektif historikalitas. Sedangkan secara spesifik tujuan pengajaran sejarah ada Tiga yaitu mengajarkan konsep, mengajarkan keterampilan intelektual dan memberikan informasi kepada peserta didik (Dennis Gunning dalam Dyah Kumalasari (2003:5) 
Dengan demikian, pengajaran tidak bertujuan untuk menghafal berbagai peristiwa sejarah. Hal ini di pertegas oleh Ahmad Syafi'i Ma'rif dalam Dyah Kumalasari (2003:6) bahwa "pengajaran sejarah yang terlalu mengedepankan aspek kognitif, tidak akan banyak pengaruhnya dalam rangka menetapkan apa yang sering disebut sebagai jati diri dan kepribadian bangsa". Lebih jauh diungkapkan pula bahwa pengajaran sejarah nasional yang antara lain bertujuan untuk mengukuhkan kepribadian bangsa dan integritas nasional sebagai bagian dari tujuan pergerakan nasional.

Dengan penanaman nilai karakter hendaknya mampu meningkatkan sikap nasionalisme siswa. Namun, pada kenyataanya nilai karakter dalam pembelajaran sejarah belum berhasil ditanamkan secara optimal, terlihat dalam pembelajaran sejarah siswa kurang faham hakekat dan makna dari materi yang disampaikan, sehingga materi tersebut hanya sebagai materi hafalan saja. Ketika ditanyakan kembali materi yang telah disampaikan siswa hanya melafalkan meteri yang telah diucapkan tapi tidak memahami meaning (makna) dari materi yang disampaikan.

Pendidikan yang berbasis karakter adalah pendidikan yang menerapkan prinsip-prinsip dan metodologi kearah pembentukan karakter anak bangsa pada peserta didiknya melalui kurikulum terintegrasi yang dikembang-kan disekolah. Kerangka pengembangan karakter melalui pembelajaran dikalangan tenaga pendidik dirasakan sangat penting. Sebagai agen perubahan, pendidik diharapkan mampu menanamkan ciri-ciri, sifat, dan watak serta jiwa mandiri, tanggung jawab, dan cakap dalam kehidupan kepada peserta didiknya. Di samping itu, karakter tersebut juga sangat diperlukan bagi seorang pendidik karena melalui jiwa ini, para pendidik akan memiliki orientasi kerja yang lebih efisien, kreatif, inovatif, produktif serta mandiri.

\section{Hasil dan Pembahasan}

\section{Pendidikan Karakter dalam Pembelajaran Sejarah}

Menurut Hasan (2011:35), Ada strategi yang dapat dilakukan untuk mengembangkan pendidikan karakter pembelajaran adalah Integrasi nilai pendidikan karakter dalam kurikulum. Pengintegrasian atau mungkin lebih tepat "alignment" adalah suatu proses memperkaya mata pelajaran atau kuliah sedang dilaksanakan dengan nilai dalam pendidikan karakter. Proses tersebut dilakukan melalui langkah-langkah berikut:

1. Memasukan nilai terpilih dari pendidikan karakter keterampilan dalam silabus, 
2. Memasukan nilai pendidikan karakter dalam rencana pelaksanaan pembelajaran (RPP) yang dikembangkan

3. Melaksanakan pembelajaran sesuai dengan RPP dengan memperhatikan proses pembelajaran untuk penguasaan keterampilan dan internalisasi nilai,

4. Melaksanakan penilaian hasil belajar.

Hal-hal yang perlu diperhatikan oleh guru dalam melaksanakan penanaman nilai-nilai pendidikan karakter agar berjalan maksimal yakni: Pertama, dimungkinkan terjadi penggabungan kompetensi dasar lintas semester. Kedua, kegiatan inti ditekankan kepada kemampuan kognisi dan mempraktikkan nilai-nilai afektif pendidikan karakter. Ketiga tematema yang dipilih disesuaikan dengan karakteristik siswa, minat, lingkungan dan daerah setempat. Keempat, kegiatan belajar mengajar tertuju pada penguasaan target (attainmenttarget) kompetensi dan karakter secara bersamaan (Sahlan, Asmaun \& Angga Teguh P, 2012:136-137).

\section{Pendidikan Karakter Sebagai Upaya Menumbuh dan Meningkatkan Kesadaran Sejarah}

Kesadaran merupakan penghayatan terhadap yang dilakukan secara sadar akan yang dialami (dilihat, didengar), dan sadar akan proses pengamatan itu sendiri yang bersifat athetis dan abstrak.

Kesadaran itu berarti pemahaman terhadap sesuatu dengan melibatkan mental, yang menyangkut ide, perasaan, pemikiran, kehendak dan ingatan yang terdapat pada diri seseorang jika ia sedang memikirkan sesuatu yang ada disekitarnya. Kesadaran sejarah adalah refleksi sikap yang bersumber pada kondisi kejiwaan yang menunjukan tingkat penghayatan, pada makna serta hakikat sejarah (I Gede Widja, 1989:556).

Kesadaran sejarah pada manusia sangat penting artinya bagi pembinaan budaya bangsa. Kesadaran sejarah dalam konteks ini bukan hanya sekedar memperluas pengetahuan, melainkan harus diarahkan pula kepada kesadaran penghayatan nilai-nilai budaya yang relevan dengan usaha pengembangan kebudayaan itu sendiri. Kesadaran sejarah dalam konteks pembinaan karakter bangsa dalam pembangkitan kesadaran bahwa bangsa itu merupakan suatu kesatuan sosial yang terwujud melalui suatu proses sejarah, yang akhirnya mempersatukan sejumlah nasion kecil dalam suatu nasion besar yaitu bangsa, pentingnya fungsi sejarah di dalam proses pembangunan dan tentu saja menyangkut dengan masa depan Indonesia, sebagai bangsa negara. 
menumbuhkan dan mengembangkan kesadaran sejarah untuk integrasi bangsa dan kesadaran nasional.

Dalam kaitan dengan proses belajar-mengajar di forum-forum akademis, suatu proses pengajaran sejarah hendaknya dapat membantu membangkitkan kesadaran sejarah para peserta didik. Jika kesadaran semacam itu nantinya bisa dimiliki oleh para peserta didik di berbagai lapisan masyarakat di negeri ini, diharapkan akan terjadi kohesi sosial yang makin erat di antara sesama warga negara, dimanapun mereka berada

\section{Implementasi Nilai Karakter Melalui Pengintegrasian Kegiatan Sekolah}

Adapun integrasi nilai karakter melalui kegiatan rutinitas disekolah sebagai berikut

1. Kegiatan rutin sekolah

Kegiatan rutin merupakan kegiatan yang dilakukan peserta didik secara terus menerus dan konsisten setiap saat. Contoh kegiatan ini adalah upacara pada hari besar kenegaraan, pemeriksaan kebersihan badan (kuku, telinga, rambut, dan lain-lain) setiap hari senin, beribadah bersama atau shalat bersama setiap dhuhur (bagi yang beragama Islam), berdoa waktu mulai dan selesai pelajaran, mengucap salam bila bertemu guru, tenaga kependidikan, atau teman

2. Kegiatan spontan

Kegiatan spontan yaitu kegiatan yang dilakukan secara spontan pada saat itu juga. Kegiatan dilakukan biasanya pada saat guru dan tenaga kependidikan yang lain mengetahui adanya perbuatan yang kurang baik dari peserta didik yang harus dikoreksi pada saat itu juga. Apabila guru mengetahui adanya perilaku dan sikap yang kurang baik maka pada saat itu juga guru harus melakukan koreksi sehingga peserta didik tidak akan melakukan tindakan yang tidak baik itu. Contoh kegiatan itu: membuang sampah tidak pada tempatnya, berteriak sehingga mengganggu pihak lain, berkelahi, memalak, berlaku tidak sopan, mencuri, berpakaian tidak senonoh. Kegiatan spontan berlaku untuk perilaku dan sikap peserta didik yang tidak baik dan yang baik sehingga perlu dipuji, misalnya: memperoleh nilai tinggi, menolong orang lain, memperoleh prestasi dalam olah raga atau kesenian, berani menentang atau mengkoreksi perilaku teman yang tidak terpuji.

3. Keteladanan 
Keteladanan adalah perilaku dan sikap guru dan tenaga kependidikan yang lain dalam memberikan contoh terhadap tindakan-tindakan baik sehingga diharapkan menjadi panutan bagi peserta didik untuk mencontohnya. Jika guru dan tenaga kependidikan yang lain menghendaki agar peserta didik berperilaku dan bersikap sesuai dengan nilai-nilai budaya dan karakter bangsa maka guru dan tenaga kependidikan yang laina dalah orang yang pertama dan utama memberikan contoh berperilaku dan bersikap sesuai dengan nilai-nilai itu. Misalnya, berpakaian rapi, datang tepat pada waktunya, bekerja keras, bertutur kata sopan, kasih sayang, perhatian terhadap peserta didik jujur, menjaga kebersihan.

4. Pengkondisian

Untuk mendukung keterlaksanaan pendidikan budaya dan karakter bangsa maka sekolah harus dikondisikan sebagai pendukung kegiatan itu. Sekolah harus mencerminkan kehidupan nilai-nilai budaya dan karakter bangsa yang diinginkan. Misalnya, toilet yang selalu bersih, bak sampah ada diberbagai tempat dan selalu dibersihkan, sekolah terlihat rapi dan alat belajar ditempatkan teratur.

\section{Implementasi Nilai Karakter Melalui Pengintegrasian dalam Mata Pelajaran}

Pengembangan nilai karakater diintegrasikan dalam setiap pokok bahasan dari setiap mata pelajaran, nilai-nilai tersebut dicantumkan dalam silabus dan RPP. Pengembangan nilainilai itu dalam silabus ditempuh melalui cara-cara berikut ini:

1) Mengkaji Standar Komptensi (SK) dan Kompetensi Dasar (KD) pada StandarIsi (SI) untuk menentukan apakah nilai-nilai budaya dan karakter bangsa yang tercantum itu sudah tercakup di dalamnya

2) Menggunakan 18 nilai karakter dan mengaikan antara SK dan KD dengan nilai dan indikator untuk menentukan nilai yang akan dikembangkan

3) Mencantumkankan nilai-nilai budaya dan karakter bangsa yang 18 ke dalam silabus

4) Mencantumkan nilai-nilai yang sudah tertera dalam silabus ke dalam RPP

5) Mengembangkan proses pembelajaran peserta didik secara aktif yang memungkinkan peserta didik memiliki kesempatan melakukan internalisasi nilai dan menunjukkannya dalam perilaku yang sesuai

6) Memberikan bantuan kepada didik, baik yang mengalami kesulitan untuk menginternalisan nilai maupun untuk menunjukkannya dalam perilaku. 
7) Budaya Sekolah Budaya sekolah cakupannya sangat luas, umumnya mencakup ritual, harapan, hubungan, demokrasi, kegiatan kurikuler, kegiatan ekstrakurikuler, proses mengambil keputusan, kebijakan maupun interaksi sosial antar komponen disekolah.

\section{Simpulan}

Fenomena rendahnya sikap Nasionalisme siswa sekarang ini sangat mengkhawatirkan dalam dunia pendidikan, tawuran antar sekolah yang meresahkan masyarakat bahkan sudah melupakan jati dirinya sebagai bangsa Indonesia dengan tidak menghargai perjuangan pahlawan Indonesia yang berkorban untuk merebut kemerdekaan dari tangan penjajah.

Dalam hal ini, pembelajaran karakter harus terintegrasi,baik alam budaya sekolah, kegiatan ekstrakurikuler, maupun kegiatan seharian di rumah dan di masyarakat.

Dalam pengembangan karakter, perlu memberikan pengetahuan dalam mengintegrasikan nilai karakter bangsa melalui pertanyaan afektif dan media pembelajaran dan seharusnya sekolah menyediakan sarana dan prasarana yang menunjang pelaksanaan pembelajaran sehingga guru dapat melaksanakan pembelajaran secara maksimal

Dalam pengembangan karakter perlu mengimplementasikan nilai karakter bangsa secara berkelanjutan (Continue) sehingga akan menjadi kebiasaan positif siswa untuk merealisasikan nya di lingkungan sehari-hari

Pembentukan karakter dimulai dari keinginan untuk mengetahui serta melaku-kan hal yang baik agar tercipta kebiasaan, baik di hati, pikiran, maupun perilaku. Dalam membentuk karakter positif, peserta didik perlu mengetahui alasan mengapa berbuat baik, merasakan hal yang baik, dan melakukan hal yang baik. Perlunya ling-kungan belajar yang positif dan peduli yang ditandai dengan penuh kasih sayang, penuh dengan kepedulian, kompetensi guru dan staf sekolah yang memberikan inspirasi dan bebas dari berbagai bentuk tindak kekerasan, serta pendidikan yang inklusif

\section{DAFTAR PUSTAKA}

Dyah Kumalasari. 2003. Hidden Curriculum Dalam Pengajaran Sejarah Dan Pembentukan Jiwa Nasionalisme, Yogyakarta: Universitas Negeri Yogyakarta. 
Hasan, S.H. (2011). Pendidikan Sejarah Untuk Memperkuat Pendidikan Karakter, Makalah dikemukakan pada Seminar Sejarah Nasional Himpunan Mahasiswa Sejarah, UNNES, 10 Nopember 2011.

I Gede widja. 1989. Dasar-Dasar Pengembangan Strategi Serta Metode Pengajaran Sejarah. Jakarta: Depdibud.

Nurul Fajri. 2013. “Implementasi Kurikulum 2013 Dalam Pembelajaran Sejarah". (online).(http://Sejarah Akademika Implementasi Kurikulum

Peraturan Menteri Pendidikan Nasional Republik Indonesia Nomor 22 Tahun 2006 Tentang Standar Isi Untuk Satuan Pendidikan Dasar dan Menengah. 2006. Jakarta: Diperbanyak oleh Biro Hukum dan Organisasi.

Sahlan, Asmaun \& Angga Teguh P. 2012. Desain Pembelajaran Berbasis Pendidikan Karakter. Jogjakarta: Ar-Ruzz Media.

Soedjadmoko. 1976. Kesadaran Sejarah Dan Pembangunan. Artikel dalam majalah prisma (penerbitan khusus). No.7 tahun V 